\title{
Effectiveness of casirivimab and imdevimab, and sotrovimab during Delta variant surge: a prospective cohort study and comparative effectiveness randomized trial
}

David T. Huang MD MPH ${ }^{1,2,3}$, Erin K. McCreary PharmD ${ }^{4}$, J. Ryan Bariola MD ${ }^{4}$, Tami E. Minnier $\mathrm{MS}^{5}$, Richard J. Wadas MD ${ }^{1}$, Judith A. Shovel BSN ${ }^{5}$, Debbie Albin BS ${ }^{6}$, Oscar C. Marroquin $\mathrm{MD}^{7}$, Kevin E. Kip $\mathrm{PhD}^{7}$, Kevin Collins MBA ${ }^{7}$, Mark Schmidhofer $\mathrm{MD}^{8}$, Mary Kay Wisniewski MA ${ }^{5}$, David A. Nace MD ${ }^{9}$, Colleen Sullivan $\mathrm{MHA}^{2,10}$, Meredith Axe BS ${ }^{1}$, Russell Meyers MBA ${ }^{1}$, Alexandra Weissman $\mathrm{MD}^{1}$, William Garrard PhD ${ }^{7}$, Octavia M. Peck-Palmer PhD ${ }^{11}$, Alan Wells MD DMSc ${ }^{11}$, Robert D. Bart MD ${ }^{3,12}$, Anne Yang $\mathrm{MD}^{13}$, Lindsay R. Berry PhD ${ }^{14}$, Scott Berry PhD ${ }^{14}$, Amy M. Crawford PhD ${ }^{14}$, Anna McGlothlin PhD ${ }^{14}$, Tina Khadem PharmD ${ }^{10}$, Kelsey Linstrum $\mathrm{MS}^{2,10}$, Stephanie K. Montgomery $\mathrm{MS}^{2,10}$, Daniel Ricketts $\mathrm{MET}^{2}$, Jason $\mathrm{N}$. Kennedy $\mathrm{MS}^{2,3}$, Caroline J. Pidro BS², Rachel L. Zapf PhD ${ }^{5}$, Paula L. Kip PhD ${ }^{5}$, Ghady Haidar MD ${ }^{4}$, Graham M. Snyder MD ${ }^{4}$, Bryan J. McVerry MD ${ }^{15}$, Donald M. Yealy $\mathrm{MD}^{1}$, Derek C. Angus MD MPH ${ }^{2,3,10}$, Christopher W. Seymour MD MSc ${ }^{2,3,10}$

\section{Author Information}

1. Department of Emergency Medicine, University of Pittsburgh School of Medicine, Pittsburgh, PA, USA

2. Clinical Research Investigation and Systems Modeling of Acute Illness (CRISMA) Center, Department of Critical Care Medicine, University of Pittsburgh School of Medicine, Pittsburgh, PA, USA

3. Department of Critical Care Medicine, University of Pittsburgh School of Medicine, Pittsburgh, PA, USA

4. Division of Infectious Diseases, Department of Medicine, University of Pittsburgh School of Medicine, Pittsburgh, PA, USA

5. Wolff Center, UPMC, Pittsburgh, PA, USA

6. Supply Chain Management/HC Pharmacy, UPMC, Pittsburgh, PA, USA

7. Clinical Analytics, UPMC, Pittsburgh, PA, USA

8. Division of Cardiology, Department of Medicine, University of Pittsburgh School of Medicine, Pittsburgh, PA, USA

9. Division of Geriatric Medicine, Department of Medicine, University of Pittsburgh School of Medicine, Pittsburgh, PA, USA

10. Health System Office of Healthcare Innovation, UPMC, Pittsburgh, PA, USA

11. Department of Pathology, University of Pittsburgh School of Medicine, Pittsburgh, PA, USA

12. Health Services Division, UPMC, Pittsburgh, PA, USA

13. Department of Medicine, University of Pittsburgh School of Medicine, Pittsburgh, PA, USA 
medRxiv preprint doi: https://doi.org/10.1101/2021.12.23.21268244; this version posted December 27, 2021. The copyright holder for this preprint (which was not certified by peer review) is the author/funder, who has granted medRxiv a license to display the preprint in perpetuity. All rights reserved. No reuse allowed without permission.

\section{mAb effectiveness in Delta}

14. Berry Consultants, Austin, TX, USA

15. Division of Pulmonary, Allergy, and Critical Care Medicine, Department of Medicine, University of Pittsburgh School of Medicine, Pittsburgh, PA, USA

\section{Running Head}

mAb effectiveness in Delta

\section{Keywords}

Monoclonal antibodies, SARS-CoV-2, COVID-19, randomized trial, comparative effectiveness, Delta variant

\section{Word Count}

2,766

\section{Corresponding Author}

David T. Huang, MD, MPH

Professor, Critical Care Medicine, Emergency Medicine, Clinical and Translational Science

UPMC and University of Pittsburgh

606B Scaife Hall

Pittsburgh, PA 15213

Email: huangdt@upmc.edu

Phone: (412) 647-6818 


\section{mAb effectiveness in Delta}

\section{Key Points}

\section{Question}

In non-hospitalized patients with mild to moderate COVID-19 due to the Delta variant, what is the effectiveness of monoclonal antibodies ( $\mathrm{mAb}$ ) compared to no treatment, and what is the comparative effectiveness between mAb?

\section{Findings}

Among 3,069 patients, mAb treatment (casirivimab and imdevimab or sotrovimab) was associated with reduced risk of hospitalization or death by 28 days compared to no treatment (risk ratio $=0.40,95 \% \mathrm{Cl}$ : 0.28-0.57). In a Bayesian randomized comparative effectiveness trial of casirivimab and imdevimab vs. sotrovimab in 3,558 patients, the median hospital-free days were 28 days for both groups. Compared to casirivimab-imdevimab, the median adjusted odds ratio for hospital-free days was 0.88 (95\% credible interval, $0.70-1.11$ ) for sotrovimab, an $86 \%$ probability of inferiority of sotrovimab versus casirivimab and imdevimab, and $79 \%$ probability of equivalence.

\section{Meaning}

In non-hospitalized patients with mild to moderate COVID-19 due to the Delta variant, casirivimab and imdevimab and sotrovimab were associated with reduced risk of hospitalization or death compared to no treatment. The comparative effectiveness of mAbs appeared similar, though prespecified criteria for statistical inferiority or equivalence were not met. 
medRxiv preprint doi: https://doi.org/10.1101/2021.12.23.21268244; this version posted December 27, 2021. The copyright holder for this

$$
\text { mAb effectiveness in Delta }
$$

\section{Abstract}

IMPORTANCE The effectiveness of monoclonal antibodies (mAbs), casirivimab and imdevimab, and sotrovimab, for patients with mild to moderate COVID-19 from the Delta variant is unknown.

OBJECTIVE To evaluate the effectiveness of mAbs for the Delta variant compared to no treatment, and the comparative effectiveness between mAbs.

DESIGN, SETTING, AND PARTICIPANTS Two parallel studies among patients who met Emergency Use Authorization criteria for mAbs from July 14, 2021 to September 29, 2021: i.) prospective observational cohort study comparing mAb treatment to no mAb treatment and, ii.) Bayesian adaptive randomized trial comparing the effectiveness of casirivimab-imdevimab versus sotrovimab. In the observational study, we compared eligible patients who received mAb at an outpatient infusion center at UPMC, to nontreated patients with a positive SARS-CoV-2 test. In the comparative effectiveness trial, we randomly allocated casirivimab-imdevimab or sotrovimab to patients presenting to infusion centers and emergency departments, per system therapeutic interchange policy.

EXPOSURE Intravenous mAb per their EUA criteria.

MAIN OUTCOMES AND MEASURES For the observational study, risk ratio estimates for hospitalization or death by 28 days were compared between mAb treatment to no mAb treatment using propensity matched models. For the comparative effectiveness trial, the primary outcome was hospital-free days (days alive and free of hospital) within 28 days, where patients who died were assigned -1 day) in a Bayesian cumulative logistic model, adjusted for treatment location, age, sex, and time. Inferiority was defined as a $99 \%$ posterior probability of an odds ratio $<1$. Equivalence was defined as a $95 \%$ posterior probability that the odds ratio is within a given bound.

RESULTS Among 3,558 patients receiving mAb, the mean age was 54 (SD 18 years), 1,511 (43\%) were treated in an infusion center, and 450 (13\%) were hospitalized or died by day 28 . In propensity matched models, mAb treatment was associated with reduced risk of hospitalization or death compared to no 
medRxiv preprint doi: https://doi.org/10.1101/2021.12.23.21268244; this version posted December 27, 2021. The copyright holder for this preprint (which was not certified by peer review) is the author/funder, who has granted medRxiv a license to display the preprint in perpetuity. All rights reserved. No reuse allowed without permission.

\section{mAb effectiveness in Delta}

treatment (risk ratio $(\mathrm{RR})=0.40,95 \% \mathrm{Cl}: 0.28-0.57)$. Both casirivimab and imdevimab $(\mathrm{RR}=0.31,95 \% \mathrm{Cl}$ :

$0.20-0.50)$, and sotrovimab ( $R R=0.60,95 \% \mathrm{Cl}: 0.37-1.00)$ reduced hospitalization or death compared to no mAb treatment. Among patients allocated randomly to casirivimab and imdevimab $(n=2,454)$ or sotrovimab $(n=1,104)$, the median hospital-free days were 28 (IQR 28-28) for both groups, 28-day mortality was $0.5 \%(n=12)$ and $0.6 \%(n=7)$, and hospitalization by day 28 was $12 \%(n=291)$ and $12 \%$ ( $n=140)$, respectively. Compared to casirivimab and imdevimab, the median adjusted odds ratio for hospital-free days was 0.88 (95\% credible interval, $0.70-1.11$ ) for sotrovimab. This odds ratio yielded $86 \%$ probability of inferiority of sotrovimab versus casirivimab and imdevimab, and $79 \%$ probability of equivalence.

CONCLUSIONS AND RELEVANCE In non-hospitalized patients with mild to moderate COVID-19 due to the Delta variant, casirivimab and imdevimab and sotrovimab were both associated with a reduced risk of hospitalization or death. The comparative effectiveness of mAbs appeared similar, though prespecified criteria for statistical inferiority or equivalence were not met.

TRIAL REGISTRATION ClinicalTrials.gov: NCT04790786 
medRxiv preprint doi: https://doi.org/10.1101/2021.12.23.21268244; this version posted December 27, 2021. The copyright holder for this

\section{mAb effectiveness in Delta}

\section{Introduction}

Monoclonal antibodies (mAbs) were granted U.S. Food and Drug Administration (FDA) Emergency Use Authorization (EUA) for treatment of mild to moderate COVID-19. ${ }^{1,2}$ However, their effectiveness with the Delta variant is unknown.

In February 2021, UPMC partnered with the U.S. Federal COVID-19 Response Team and received bamlanivimab, bamlanivimab-etesevimab, and casirivimab-imdevimab to expand clinical use and evaluate their effectiveness using a learning health system approach. This approach embeds knowledge generation into daily practice to seek continuous improvement in care. ${ }^{3,4,5}$ In April 2021, the EUA for bamlanivimab was revoked, and in June 2021, UPMC partnered with GlaxoSmithKline and Vir Biotechnology to make sotrovimab available to EUA-eligible patients and evaluate its effectiveness. Because the U.S. government paused distribution of bamlanivimab-etesevimab, and the Delta variant became dominant in the U.S in summer 2021, we evaluated the effectiveness of casirivimab-imdevimab and sotrovimab from July 2021 to September $2021.6,7$

This report presents an evaluation of casirivimab-imdevimab and sotrovimab from July 14, 2021 to September 29, 2021, with results released due to the Delta variant public health crisis. This study sought to determine, i) the effectiveness of mAbs for the Delta variant compared to no treatment, and ii) the comparative effectiveness between mAbs. 
medRxiv preprint doi: https://doi.org/10.1101/2021.12.23.21268244; this version posted December 27, 2021. The copyright holder for this

$$
\text { mAb effectiveness in Delta }
$$

\section{Methods}

This report includes two studies: i) a propensity score matched observational study of mAb treatment versus no mAb treatment (UPMC Quality Improvement Review Committee Project ID 2882 and Project ID 3116), and ii) a randomized comparative effectiveness trial of casirivimab and imdevimab versus sotrovimab (UPMC Quality Improvement Committee Project ID 3280 and University of Pittsburgh Institutional Review Board (IRB) STUDY21020179).

\section{Study setting and data sources}

UPMC is a 40-hospital integrated health system principally in central and western Pennsylvania. After an EUA was granted for bamlanivimab on November $9,2020,{ }^{8}$ UPMC developed a mAb treatment infrastructure. ${ }^{9,10}$ On November 21, 2020, the UPMC Pharmacy and Therapeutics Committee wrote a therapeutic interchange policy in response to the issuance of an EUA for casirivimab and imdevimab and unpredictable mAb supply. The policy considered all available mAbs equivalent; a patient could receive any mAb based on local inventory. The policy was updated to include sotrovimab on July 9, 2021. All pharmacies supplying all infusion sites had equal opportunity to order any available mAb from a central supply facility. Prescribers were required to provide and review all mAb EUA Fact Sheets with the patient at time of referral and explain the patient could receive any EUA-governed mAb under the therapeutic interchange policy. EUA-eligible patients were referred via the electronic medical record (EMR) systems for UPMC providers and by paper order for non-UPMC prescribers. A centralized team with nurses, administrators, pharmacists, and physicians reviewed orders daily to confirm criteria for receipt. Decentralized nursing teams then contacted and scheduled eligible patients for infusions. 
medRxiv preprint doi: https://doi.org/10.1101/2021.12.23.21268244; this version posted December 27, 2021. The copyright holder for this preprint (which was not certified by peer review) is the author/funder, who has granted medRxiv a license to display the preprint in perpetuity. All rights reserved. No reuse allowed without permission.

mAb effectiveness in Delta

We used the EMR to access all key clinical data including detailed sociodemographic and medical history data, and hospitalization after mAb treatment, and augmented by manual review and data collection. We linked the deidentified primary data sources using common variables within the UPMC data systems aggregated in its Clinical Data Warehouse. We conducted Social Security Administration Death Master File queries for vital status. ${ }^{11}$

\section{Exposure}

Both mAb were provided as per their EUAs and were provided intravenously for all patients in this report. Patients who received casirivimab and imdevimab via subcutaneous injection were excluded from the analysis.

\section{Propensity-matched observational study of mAb treatment versus no mAb treatment}

\section{Patient cohort}

The study population was derived from patients who received mAb treatment at UPMC infusion centers from July 14, 2021 to September 29, 2021. We derived a comparator group from the same at-risk population by identifying non-hospitalized patients with a positive polymerase chain reaction or antigen test for SARS-CoV-2 during the same time period who were eligible for mAb treatment based on EUA criteria but were not treated. For treated patients, the follow-up period began the day of treatment. For comparator patients, the follow-up period began one day after their SARS-CoV-2 test result date, which corresponded to the earliest time from test positivity to mAb treatment for treated patients. We 
medRxiv preprint doi: https://doi.org/10.1101/2021.12.23.21268244; this version posted December 27, 2021. The copyright holder for this

\section{mAb effectiveness in Delta}

conducted the analysis on patients treated at infusion centers, as it was not possible to identify a comparator group for patients treated in EDs.

\section{Outcomes}

The primary outcome was hospitalization or death by 28 days. Secondary outcomes included the 28-day rate of hospitalization, ICU admission, mechanical ventilation, and mortality.

\section{Statistical analysis}

We performed three analyses. We used propensity matching to compared mAb-eligible patients to, i) all mAb treated patients, ii.) casirivimab and imdevimab treated patients, and iii.) sotrovimab treated patients, respectively. Propensity scores were derived from multivariable logistic regression models fit from variables with mAb treatment as the response variable and forward stepwise selection of pretreatment explanatory variables at $p<0.15$. We included variables deemed biologically relevant (e.g., age) prior to stepwise selection. We used a matching ratio (treated/untreated) of 1:2 with a maximum propensity score probability difference of 0.01 . We compared characteristics of treated versus nontreated patients using Student $t$ tests for continuous variables and $\chi 2$ tests for categorical variables, prior to and after matching by propensity score. The primary outcome analysis consisted of the 1:2 matched comparisons of treated patients to non-treated control patients, with study outcomes expressed as an effect estimate of treatment (risk ratio, $95 \%$ confidence interval). Because of the similarity of casirivimab and imdevimab and sotrovimab treated patients (including nearly identical distributions of propensity scores), and to insure the same reference group (untreated patients) for comparison, the full set of matched controls was used in all analyses. 
medRxiv preprint doi: https://doi.org/10.1101/2021.12.23.21268244; this version posted December 27, 2021. The copyright holder for this

\author{
mAb effectiveness in Delta
}

\title{
Comparative effectiveness trial of casirivimab and imdevimab versus
}

\section{sotrovimab}

The Bayesian adaptive platform trial provided the mAb therapeutic interchange via random allocation. The UPMC Quality Improvement Committee approved the study, including the random therapeutic interchange. The University of Pittsburgh IRB considered the randomized therapeutic interchange to be quality improvement and approved the additional data collection and analyses. A custom application built into the EMR linked local inventory to patient encounters and provided a random mAb allocation at time of $\mathrm{mAb}$ referral. Patients provided verbal consent to receive mAb therapy as part of routine care within the EUA. The prescriber and/or patient could request a specific mAb if desired.

\section{Patient cohort}

The primary analysis population was the "as-infused" population of all patients allocated to sotrovimab or casirivimab and imdevimab, and who received mAb treatment at UPMC infusion centers and EDs during the study period. As all arms included mAb, there was no anticipated relationship between lack of infusion and the assigned arm. Due to episodic mAb shortages, some patients were treated at sites with only one available mAb at the time of treatment. We included these patients in the primary analysis as prescribing physicians and patients were blinded to drug availability at time of randomization and patients could be treated at a site different than the randomization site, pending scheduling availability.

\section{Outcomes}


medRxiv preprint doi: https://doi.org/10.1101/2021.12.23.21268244; this version posted December 27, 2021. The copyright holder for this

mAb effectiveness in Delta

The primary outcome was hospital-free days up to day 28 after mAb treatment. This outcome is an ordinal endpoint with death as the worst outcome (labeled -1), then the length of time alive and free of hospitalization, such that the best outcome would be 28 hospital-free days. If a patient had intervening days free of hospital and was then re-hospitalized, the patient was given credit for the intervening days as free of the hospital. The secondary outcome was mortality at 28 days. We evaluated outcomes stratified by infusion location (ED versus infusion center), and the frequency of adverse events. We assessed SARS-CoV-2 variant prevalence in a random subset of enrolled patients and in our Pennsylvania catchment using Global Initiative on Sharing All Influenza Data (GISAID). ${ }^{7}$

\section{Statistical Analysis}

The trial statistical analysis plan was written by blinded investigators prior to data lock and analysis. The platform is designed to continuously evaluate multiple $\mathrm{mAb}$, with randomization continuing until predetermined statistical thresholds are met. The trial launched with equal allocation randomization and planned interim analyses for adaptive randomization where mAb performing better would be given higher randomization probabilities. The mAb arm at the first adaptive analysis with the largest sample size was specified as the referent arm, as there was no non-mAb control and all patients received active treatment. Methods and results are reported as per the CONSORT Pragmatic Extension checklist (Supplement 2). ${ }^{12}$ An unblinded statistical analysis committee conducted interim and final analyses with R version 4.0.5 using the RStan package version 2.21.0 (R Foundation, Vienna, Austria) and reported results to the UPMC Chief Medical Officer who functioned in a data and safety monitor role for the study.

The primary model was a Bayesian cumulative logistic model that adjusted for treatment location (infusion center or ED), age (<30, 30-39, 40-49, 50-59, 60-69, 70-79, and $\geq 80$ years), sex, and time (2- 
medRxiv preprint doi: https://doi.org/10.1101/2021.12.23.21268244; this version posted December 27, 2021. The copyright holder for this preprint (which was not certified by peer review) is the author/funder, who has granted medRxiv a license to display the preprint in perpetuity. All rights reserved. No reuse allowed without permission.

\section{mAb effectiveness in Delta}

week epochs). The comparison between individual mAbs were based on the relative odds ratio between a given two arms for the ordinal primary outcome. An odds ratio for an arm to a comparator greater than 1 implies improved outcomes on the ordinal scale. A sliding scale with different levels of equivalence bounds was pre-defined. Equivalence between two arms was defined as a 95\% posterior probability that the odds ratio is within a given odds ratio bound. Inferiority of one arm compared to another was defined as a $99 \%$ posterior probability of an odds ratio less than 1.

\section{Secondary analyses}

We conducted a sensitivity analysis that excluded patients who received a mAb infusion at a site with only one available mAb treatment option in their "as infused" group. We conducted a priori subgroup analyses by vaccine status (full, partial, unvaccinated, unknown), symptom onset ( $>5$ days, $\leq 5$ days), and location (infusion center, ED).

\section{Decision to publish interim results}

Due to the Delta variant public health crisis, we unblinded and analyzed patients allocated through September 29, 2021, prior to having knowingly met any pre-specified statistical threshold. 
medRxiv preprint doi: https://doi.org/10.1101/2021.12.23.21268244; this version posted December 27, 2021. The copyright holder for this

\author{
mAb effectiveness in Delta
}

\title{
Results
}

\section{Propensity-matched observational study of mAb treatment versus no mAb}

\section{treatment}

The mean age (SD) of the 1,028 treated patients was $53(16)$ years versus 49 (21) years for the 5,171

patients who did not receive mAb $(p<.001)$. Treated patients were less likely than no mAb patients to be of Black race, had lower mean Charlson Comorbidity Index scores, and more likely to have greater body mass index. After propensity score matching, treated and non-mAb treated patients were similar for all variables included in the propensity score model, the distribution of propensity scores, and variables not included in the model (eFigure 2, eTable 1).

Of the 1,023 propensity-matched patients who received mAb at an infusion center, 35 (3\%) were hospitalized or died, and of the 2,046 propensity-matched patients who did not receive mAb, 174 (8.5\%) were hospitalized or died. The mortality rate was $2.9 \%(n=60)$. In the propensity matched analysis, patients receiving mAb had lower adjusted risk of hospitalization or death (risk ratio $0.40,95 \% \mathrm{Cl}: 0.28-$ 0.57), compared to no mAb treatment. Of the 712 propensity-matched patients who received casirivimab and imdevimab, $19(2.7 \%)$ were hospitalized and one died $(0.1 \%)$, with lower adjusted risk of hospitalization or death (risk ratio $0.31,95 \% \mathrm{Cl}: 0.20-0.50$ ), compared to no mAb treatment. Of the 311 propensity-matched patients who received sotrovimab, 16 (5.1\%) were hospitalized and none died, yielding lower adjusted risk of hospitalization or death (risk ratio $0.60,95 \% \mathrm{Cl}: 0.37-1.00$ ), compared to no mAb treatment. Unmatched analyses had similar results (eTable 2). 
medRxiv preprint doi: https://doi.org/10.1101/2021.12.23.21268244; this version posted December 27, 2021. The copyright holder for this

mAb effectiveness in Delta

\section{Comparative effectiveness trial of casirivimab and imdevimab versus}

\section{sotrovimab}

Among 4,530 referred and allocated patients, 3,558 (79\%) were infused (casirivimab and imdevimab, $\mathrm{n}=2454$, sotrovimab, $n=1104$, Figure 1). The mean age across groups was 54 years, half were female (54\%), $12 \%$ were Black, and the most common risk factors were body mass index $>25$, age $\geq 65$ years, and hypertension. Mean duration of symptom onset to infusion was 5.9 days. Of those allocated to a $\mathrm{mAb}$ but excluded ( $\mathrm{N}=972$ ), most were not infused due to declining treatment or inability to contact $(N=437,45 \%)$, undetermined reasons $(N=183,19 \%)$, or were scheduled but not infused $(N=116,12 \%)$. One patient requested a specific mAb different than randomized assignment. All patients $(\mathrm{N}=79)$ tested for variant type had Delta, consistent with Pennsylvania GSAID data for this time period which showed nearly all cases were Delta (eFigure 1). Baseline characteristics were similar across groups (Table 2).

\section{Primary outcome}

The median hospital-free days were 28 (IQR 28-28) (Table 3, Figure 2). Relative to the casirivimab and imdevimab group, the posterior median adjusted odds ratios from the primary model was 0.88 (95\% credible interval, $0.70-1.11$ ) for the sotrovimab group. This odds ratio resulted in an $86 \%$ probability of inferiority for sotrovimab versus casirivimab and imdevimab. The probability of equivalence between sotrovimab and casirivimab and imdevimab at the first pre-specified bound was $79 \%$. No comparison met prespecified criteria for statistical inferiority or equivalence.

\section{Secondary outcomes}

The 28 -day mortality rates were $0.5 \%(12 / 2,454)$ and $0.6 \%(7 / 1,104)$, and hospitalization rates were $11.9 \%(291 / 2,454)$ and $12.7 \%(140 / 1,104)$, in the casirivimab and imdevimab, and sotrovimab groups, 
medRxiv preprint doi: https://doi.org/10.1101/2021.12.23.21268244; this version posted December 27, 2021. The copyright holder for this preprint (which was not certified by peer review) is the author/funder, who has granted medRxiv a license to display the preprint in perpetuity. All rights reserved. No reuse allowed without permission.

\author{
mAb effectiveness in Delta
}

respectively (Table 3). For patients receiving $m A b$ in an $E D$, rates of hospitalization after treatment were $18.7 \%(262 / 1,399)$ for casirivimab and imdevimab and $17.4 \%(113 / 648)$ for sotrovimab. For patients receiving $m A b$ in an infusion center, rates of hospitalization after treatment were $2.7 \%(29$ of 1,055$)$ for casirivimab and imdevimab and $5.9 \%$ (27 of 456$)$ for sotrovimab.

\title{
Sensitivity and subgroup analyses
}

We performed multiple sensitivity analyses to determine the robustness of our results. First, we excluded patients $(n=1,162)$ who received casirivimab and imdevimab at a location where only casirivimab and imdevimab was available and found similar results ( $81 \%$ probability of sotrovimab inferiority to casirivimab and imdevimab, $79 \%$ equivalence). No subgroup analysis except location met the pre-specified thresholds for statistical inferiority or equivalence. Among the 1,511 patients treated at an infusion center, the median odds ratio of sotrovimab compared to casirivimab and imdevimab was 0.48 (95\% credible interval, $0.28-0.84)$, resulting in a $99.5 \%$ probability of inferiority.

\section{Adverse events}

Among the 2,454 patients treated with casirivimab and imdevimab, adverse events (AE) and serious adverse events (SAE) were rare, reported in $17(0.5 \%)$ and $7(0.2 \%)$ of patients, respectively. Similarly, for the 1,104 sotrovimab treated patients, respective rates were $0.5 \%$ ( 6 patients) and $0.4 \%$ (4 patients). The most commonly reported AE were flushing, itching, breathing difficulties, and chest tightness/pain. 
medRxiv preprint doi: https://doi.org/10.1101/2021.12.23.21268244; this version posted December 27, 2021. The copyright holder for this

$$
\text { mAb effectiveness in Delta }
$$

\section{Discussion}

During the COVID-19 Delta variant surge, we found that casirivimab-imdevimab and sotrovimab were each associated with a reduced risk-adjusted hospitalization and death among patients with mild to moderate COVID-19 compared to no treatment. In a comparative effectiveness randomized trial, no primary analysis met a prespecified trigger for conclusions of inferiority or equivalence, although the subgroup analysis of patients treated in an infusion center found superiority of casirivimab-imdevimab over sotrovimab.

The Delta variant of SARS-CoV-2 was observed late 2020, and by July 2021 was the dominant strain worldwide. Yet, early evidence that demonstrated the efficacy of mAb were conducted prior to the emergence of Delta. Our data extend earlier work to show that mAbs are associated with improved outcomes in Delta in a cohort with a robust sample size and methods to adjust for treatment selection and confounding. Future work will determine effectiveness versus the Omicron variant.

We found no difference when comparing the effectiveness of mAb according to predefined statistical thresholds. This finding could be due to true absence of a difference or from insufficient power to detect a difference due to our decision to evaluate early because of pandemic emergency. In an a priori subgroup, we did observe a $99.5 \%$ probability of inferiority in patients treated at an infusion center. Although not a primary analysis, this finding, if replicated, suggests that at least for patients with the Delta variant treated in an infusion center, casirivimab-imdevimab may be preferred. Patients presenting to an ED may have a greater illness severity compared to patients presenting to a scheduled appointment at an infusion center, and their illness severity may be the main determinant of their subsequent course, not mAb type received. 
medRxiv preprint doi: https://doi.org/10.1101/2021.12.23.21268244; this version posted December 27, 2021. The copyright holder for this preprint (which was not certified by peer review) is the author/funder, who has granted medRxiv a license to display the preprint in perpetuity. All rights reserved. No reuse allowed without permission.

\author{
mAb effectiveness in Delta
}

There are many limitations to these studies. First, the observational analysis of mAb treatment versus no mAb treatment may be subject to residual or unmeasured confounding. Second, we evaluated comparative effectiveness trial results early due to the Delta variant crisis and the primary analysis was inconclusive. Third, this report is restricted to the patients in the catchment of UPMC, limiting generalizability. Finally, we were not powered to determine treatment effects by symptom onset or vaccine status. 
medRxiv preprint doi: https://doi.org/10.1101/2021.12.23.21268244; this version posted December 27, 2021. The copyright holder for this preprint (which was not certified by peer review) is the author/funder, who has granted medRxiv a license to display the preprint in perpetuity. All rights reserved. No reuse allowed without permission.

\section{Conclusion}

In non-hospitalized patients with mild to moderate COVID-19 due to the Delta variant, casirivimab and imdevimab, and sotrovimab were both associated with reduced risk of hospitalization or death. The comparative effectiveness of mAbs appeared similar, though prespecified criteria for statistical inferiority or equivalence were not met. 
medRxiv preprint doi: https://doi.org/10.1101/2021.12.23.21268244; this version posted December 27, 2021. The copyright holder for this

\section{mAb effectiveness in Delta}

\section{Article Information}

\section{Acknowledgements}

The authors thank the clinical staff of the UPMC monoclonal antibody infusion centers as well as the support and administrative staff behind this effort, including but not limited to: Michelle Adam, Jodi Ayers, Ashley Beyerl, Trudy Bloomquist, Tina Borneman, Mikaela Bortot, Jonya Brooks, James Cable, Sherry Casali, Jeana Colella, Jennifer Dueweke, Jesse Duff, Janice Dunsavage, Jessica Fesz, Kathleen Flinn, Daniel Gessel, Amy Helmuth, Erik Hernandez, Larry Hruska, Allison Hydzik, Le Ann Kaltenbaugh, LuAnn King, Jim Krosse, Sheila Kruman, Amy Lukanski, Hilary Maskiewicz, Debra Masser, Katelyn Mayak, Rebecca Medva, Theresa Murillo, Melanie Pierce, Teressa Polcha, Kevin Pruznak, Debra Rogers, Rozalyn Russell, Sarah Sakaluk, Heather Schaeffer, Robert Shulik, Libby Shumaker, Susan Spencer, Ashley Steiner, Betsy Tedesco, Ken Trimmer, Jennifer Zabala, and their entire teams.

\section{Affiliations of Authors/members of the writing committee}

We acknowledge staff at UPMC Clinical Analytics, the UPMC Wolff Center, and Biostatistics and Data Management Core at the CRISMA Center in the Department of Critical Care Medicine at the University of Pittsburgh for curating and managing the data.

\section{Author contributions}

Dr. Huang and Seymour take full responsibility for the integrity of the data and the accuracy of the data analysis.

Study concept and design: Huang, McCreary, Kip, Seymour Acquisition of data: Huang, McCreary, Collins, Kip, Seymour Interpretation of data: All authors

Drafting of the manuscript: Huang, Seymour 
medRxiv preprint doi: https://doi.org/10.1101/2021.12.23.21268244; this version posted December 27, 2021. The copyright holder for this preprint (which was not certified by peer review) is the author/funder, who has granted medRxiv a license to display the preprint in perpetuity. All rights reserved. No reuse allowed without permission.

\section{mAb effectiveness in Delta}

Critical revision of the manuscript for important intellectual content: All authors

Study supervision: Huang, Seymour

\section{Conflict of Interest Disclosures}

No authors report disclosures, conflict of interest or relevant financial interests related to the content of the manuscript.

\section{Funding/Support}

This work received no external funding. The U.S. federal government provided casirivimab and imdevimab and GlaxoSmithKline/Vir Biotechnology provided sotrovimab. Preliminary results were shared with GlaxoSmithKline/Vir Biotechnology prior to pre-print submission; they had no role in manuscript preparation or interpretation of results. 
medRxiv preprint doi: https://doi.org/10.1101/2021.12.23.21268244; this version posted December 27, 2021. The copyright holder for this preprint (which was not certified by peer review) is the author/funder, who has granted medRxiv a license to display the preprint in perpetuity.

All rights reserved. No reuse allowed without permission.

\section{mAb effectiveness in Delta}

\section{Summary of Supplements}

\section{Supplement 1 - Online Supplemental Materials}

eFigure 1. SARS-CoV-2 Variants of Concern Proportion in Pennsylvania During the Study

eFigure 2. Propensity Scores for Unmatched and Matched Patients

eTable 1. Comparison of Characteristics of Unmatched and Propensity Matched Patients

eTable 2. Primary and Secondary Outcomes in an Unmatched Cohort of Patients Receiving Monoclonal Antibody Treatment and an At-Risk Population of Patients Not Receiving Monoclonal Antibody

Treatment

\section{Supplement 2 - CONSORT Pragmatic Trials Checklist}


medRxiv preprint doi: https://doi.org/10.1101/2021.12.23.21268244; this version posted December 27, 2021. The copyright holder for this

$$
\text { mAb effectiveness in Delta }
$$

\section{References}

1. Food and Drug Administration. Fact sheet for health care providers emergency use authorization (EUA) of REGEN-COVTM. November 21, 2020. https://www.fda.gov/media/143894/download. Accessed July 20, 2021.

2. Food and Drug Administration. Frequently asked questions on the emergency use authorization of sotrovimab. May 26, 2021. https://www.fda.gov/media/149535/download. Accessed October 13, 2021.

3. Angus DC. Optimizing the Trade-off Between Learning and Doing in a Pandemic. JAMA. May 19 2020;323(19):1895-1896. doi:10.1001/jama.2020.4984.

4. Institute of Medicine. The Learning Healthcare System: Workshop Summary. July 2007. https://pubmed.ncbi.nIm.nih.gov/21452449/. Accessed October 13, 2021.

5. McCreary EK, Bariola JR, Minnier T, et al. A Learning Health System Randomized Trial of Monoclonal Antibodies for COVID-19. medRxiv. 2021:2021.09.03.21262551. doi:10.1101/2021.09.03.21262551.

6. Department of Health and Human Services. Pause in the distribution of bamlanivimab/etesevimab. June 25, 2021. https://www.phe.gov/emergency/events/COVID19/investigationMCM/BamlanivimAb-etesevimAb/Pages/bamlanivimAb-etesevimAb-distribution-pause.aspx. Accessed July 20, 2021.

7. Global Information Sharing All Influenza Data. Tracking of variants. July 20, 2021. https://www.gisaid.org/. Accessed October 13, 2021.

8. Food and Drug Administration. Fact sheet for health care providers emergency use authorization (EUA) of bamlanivimab. November 9, 2021. https://www.fda.gov/media/143603/download. Accessed July 20, 2021.

9. Angus DC. Fusing Randomized Trials With Big Data: The Key to Self-learning Health Care Systems? Jama. Aug 25 2015;314(8):767-8. doi:10.1001/jama.2015.7762. 
medRxiv preprint doi: https://doi.org/10.1101/2021.12.23.21268244; this version posted December 27, 2021. The copyright holder for this preprint (which was not certified by peer review) is the author/funder, who has granted medRxiv a license to display the preprint in perpetuity. All rights reserved. No reuse allowed without permission.

\author{
mAb effectiveness in Delta
}

10. Bariola JR, McCreary EK, Khadem T, et al. Establishing a Distribution Network for COVID-19

Monoclonal Antibody Therapy Across a Large Health System During a Global Pandemic. Open Forum Infect Dis. Jul 2021;8(7):ofab151. doi:10.1093/ofid/ofab151.

11. Social Security Administration. Social security master file of social security number holders and applications: Death information. October 13, 2021.

https://www.ssa.gov/dataexchange/request_dmf.html. Accessed October 13, 2021.

12. Zwarenstein M, Treweek S, Gagnier JJ, et al. Improving the reporting of pragmatic trials: an extension of the CONSORT statement. BMJ (Clinical research ed). Nov 11 2008;337:a2390. doi:10.1136/bmj.a2390. 
medRxiv preprint doi: https://doi.org/10.1101/2021.12.23.21268244; this version posted December 27, 2021. The copyright holder for this preprint (which was not certified by peer review) is the author/funder, who has granted medRxiv a license to display the preprint in perpetuity.

All rights reserved. No reuse allowed without permission.

mAb effectiveness in Delta

Figure 1. CONSORT Diagram

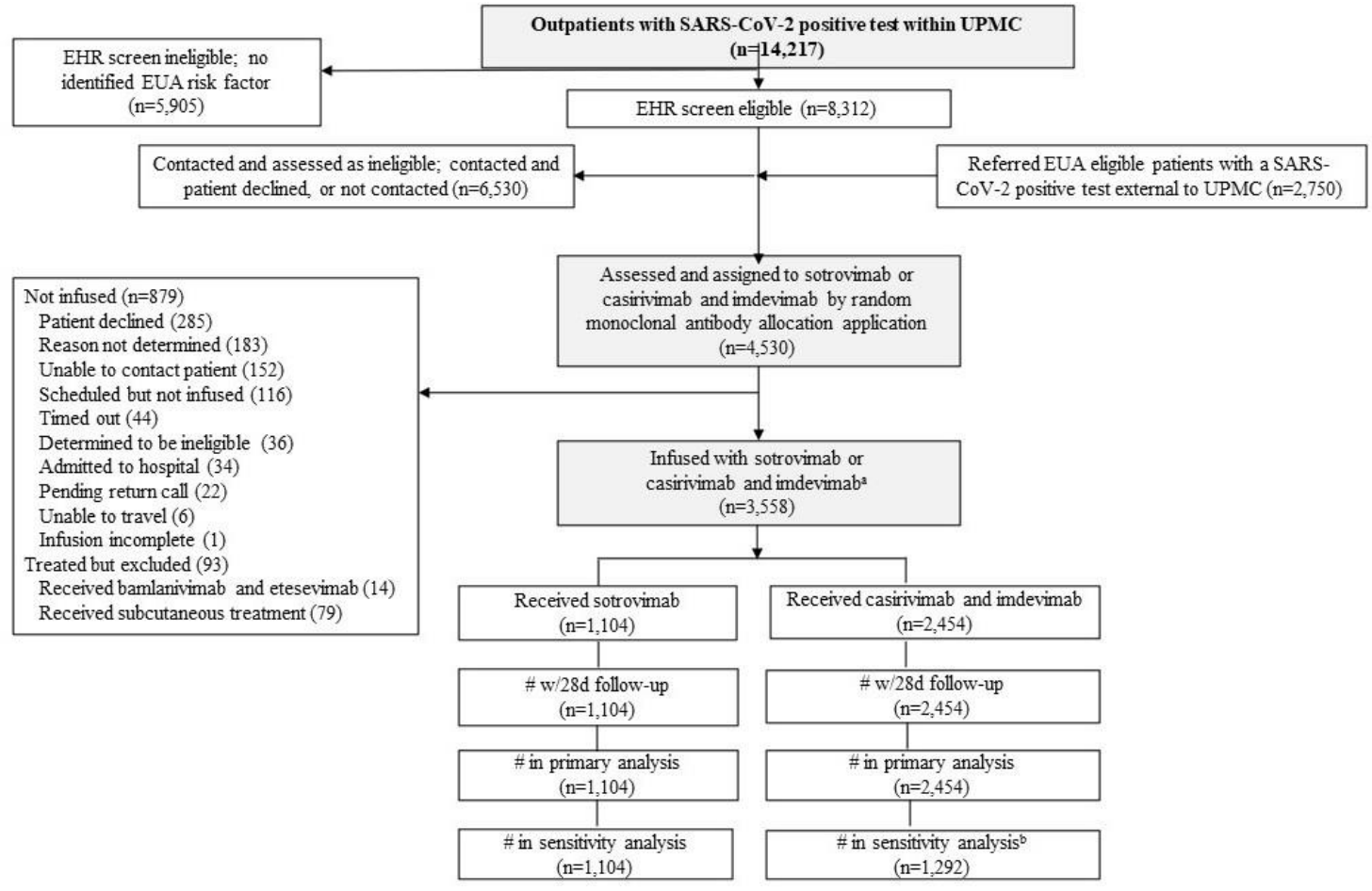


medRxiv preprint doi: https://doi.org/10.1101/2021.12.23.21268244; this version posted December 27, 2021. The copyright holder for this preprint (which was not certified by peer review) is the author/funder, who has granted medRxiv a license to display the preprint in perpetuity.

All rights reserved. No reuse allowed without permission.

mAb effectiveness in Delta

Figure 2. Hospital-Free Days to Day 28 in comparative effectiveness trial

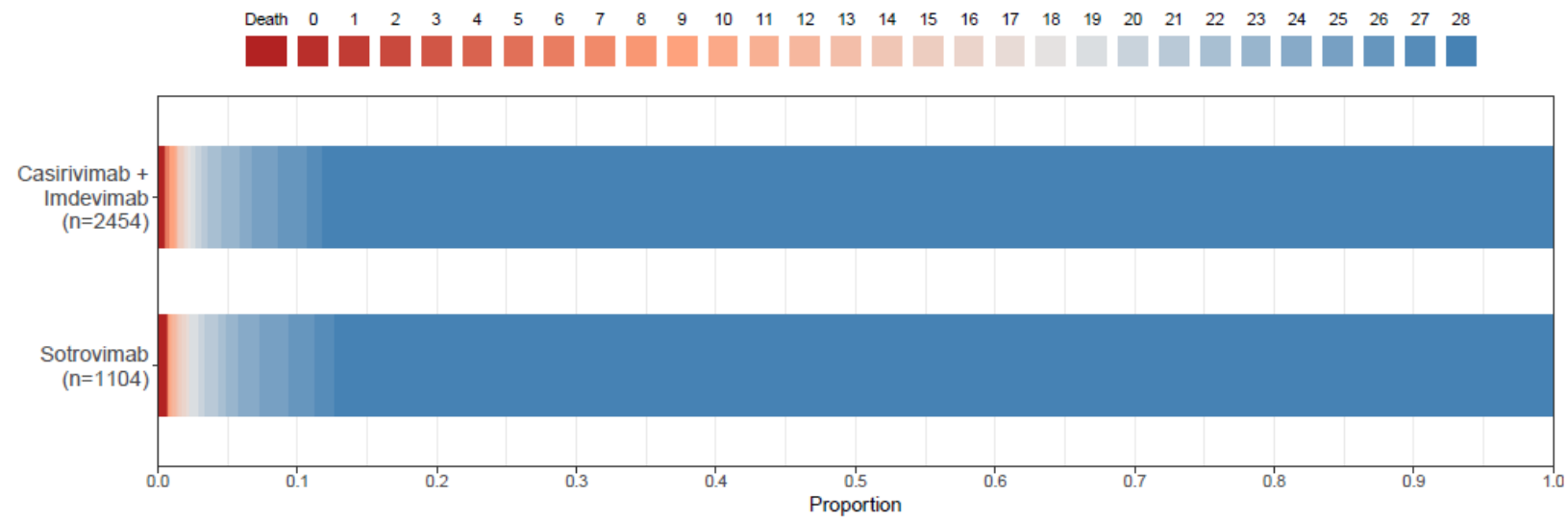

Primary outcome is displayed as horizontally stacked proportions by monoclonal antibody type. Red represents worse values and blue represents better values. The median adjusted odds ratio from the primary analysis, using a Bayesian cumulative logistic model, was 0.88 (95\% credible interval, 0.70-1.11) for sotrovimab versus casirivimab and imdevimab. This odds ratio yielded $86 \%$ probability of inferiority for sotrovimab versus casirivimab and imdevimab, and $79 \%$ probability of equivalence between the two at the first pre-specified bound. 
medRxiv preprint doi: https://doi.org/10.1101/2021.12.23.21268244; this version posted December 27, 2021. The copyright holder for this preprint (which was not certified by peer review) is the author/funder, who has granted medRxiv a license to display the preprint in perpetuity.

All rights reserved. No reuse allowed without permission.

mAb effectiveness in Delta

Table 1. Adjusted rates of hospitalization or mortality comparing mAb treatment to no mAb treatment

\begin{tabular}{|c|c|c|c|c|c|c|c|}
\hline & \multicolumn{2}{|c|}{ Number of Events } & \multicolumn{2}{|c|}{ 28-Day Event Rate (\%) } & \multicolumn{3}{|c|}{ Risk Ratio Estimates } \\
\hline & Treated & Not Treated & Treated & Not Treated & Risk Ratio & $(95 \% \mathrm{Cl})$ & p-value \\
\hline \multicolumn{8}{|c|}{ Casirivimab + Imdevimab vs. Not Treated } \\
\hline No. & 712 & 2,046 & & & & & \\
\hline Hospitalization or mortality & 19 & 174 & $2.7 \%$ & $8.5 \%$ & 0.31 & $(0.20-0.50)$ & $<.001$ \\
\hline Hospitalization & 19 & 134 & $2.7 \%$ & $6.6 \%$ & 0.41 & $(0.25-0.65)$ & $<.001$ \\
\hline Mortality & 1 & 60 & $0.1 \%$ & $2.9 \%$ & 0.05 & $(0.01-0.34)$ & .003 \\
\hline \multicolumn{8}{|l|}{ Sotrovimab vs. Not Treated } \\
\hline No. & 311 & 2,046 & & & & & \\
\hline Hospitalization or mortality & 16 & 174 & $5.1 \%$ & $8.5 \%$ & 0.60 & $(0.37-1.00)$ & .05 \\
\hline Hospitalization & 16 & 134 & $5.1 \%$ & $6.6 \%$ & 0.79 & $(0.47-1.30)$ & .35 \\
\hline Mortality & 0 & 60 & $0.0 \%$ & $2.9 \%$ & 0.0 & & \\
\hline \multicolumn{8}{|l|}{ All $m A b$ vs. Not Treated } \\
\hline No. & 1,023 & 2,046 & & & & & \\
\hline Hospitalization or mortality & 35 & 174 & $3.4 \%$ & $8.5 \%$ & 0.40 & $(0.28-0.57)$ & $<.001$ \\
\hline Hospitalization & 35 & 134 & $3.4 \%$ & $6.6 \%$ & 0.52 & $(0.36-0.75)$ & $<.001$ \\
\hline Mortality & 1 & 60 & $0.1 \%$ & $2.9 \%$ & 0.03 & $(0.01-0.34)$ & $<.001$ \\
\hline
\end{tabular}

Abbreviations: $\mathrm{Cl}$ : confidence interval 
medRxiv preprint doi: https://doi.org/10.1101/2021.12.23.21268244; this version posted December 27, 2021. The copyright holder for this preprint (which was not certified by peer review) is the author/funder, who has granted medRxiv a license to display the preprint in perpetuity. All rights reserved. No reuse allowed without permission.

mAb effectiveness in Delta

Table 2. Characteristics of mAb treated patients

\begin{tabular}{|c|c|c|c|}
\hline & $\begin{array}{c}\text { Casirivimab } \\
+ \text { Imdevimab }\end{array}$ & Sotrovimab & Entire Cohort \\
\hline No. & $2,454(69 \%)$ & $1,104(31 \%)$ & 3,558 \\
\hline \multicolumn{4}{|l|}{ Patient Characteristics } \\
\hline Age, mean (SD) & $54(18)$ & $53(18)$ & $54(18)$ \\
\hline Female sex, $\mathrm{n}(\%)$ & $1,320(54 \%)$ & $599(54 \%)$ & $1,919(54 \%)$ \\
\hline \multicolumn{4}{|l|}{ Race, n (\%) } \\
\hline White & $2,089(85 \%)$ & $892(81 \%)$ & $2,981(84 \%)$ \\
\hline Black & 252 (10\%) & $161(15 \%)$ & $413(12 \%)$ \\
\hline Other & $50(2 \%)$ & $27(2 \%)$ & $77(2 \%)$ \\
\hline Unknown & $63(3 \%)$ & $24(2 \%)$ & $87(2 \%)$ \\
\hline \multicolumn{4}{|l|}{ Vaccine status, n (\%) } \\
\hline Fully vaccinated & $632(26 \%)$ & $300(27 \%)$ & $932(26 \%)$ \\
\hline Partially vaccinated & $82(3 \%)$ & $39(3.5 \%)$ & $121(4 \%)$ \\
\hline Unvaccinated & 499 (20\%) & $182(17 \%)$ & $681(19 \%)$ \\
\hline Unknown & $1,241(51 \%)$ & $583(53 \%)$ & $1,824(51 \%)$ \\
\hline Body mass index, mean (SD) & $32.7(8.0)$ & $32.4(7.7)$ & $32.6(7.9)$ \\
\hline \multicolumn{4}{|l|}{ Timing of randomization } \\
\hline Days from randomization to infusion, mean (SD) & $0.7(1.2)$ & $0.6(1.0)$ & $0.7(1.2)$ \\
\hline Days from symptoms to randomization, mean (SD) & $4.5(2.0)$ & $4.6(2.1)$ & $4.5(2.0)$ \\
\hline Days from symptoms to infusion, mean (SD) & $6.0(1.9)$ & $5.8(2.0)$ & $5.9(1.9)$ \\
\hline \multicolumn{4}{|l|}{ mAb Treatment Sites } \\
\hline \multicolumn{4}{|l|}{ Location, n (\%) } \\
\hline Infusion center & $1,055(43 \%)$ & $456(41 \%)$ & $1,511(43 \%)$ \\
\hline Emergency department & $1,399(57 \%)$ & $648(59 \%)$ & $2,047(58 \%)$ \\
\hline \multicolumn{4}{|l|}{ mAb Treatment Eligibility } \\
\hline \multicolumn{4}{|l|}{ Qualifying EUA criteria, n (\%) } \\
\hline Age $\geq 65$ years & $772(32 \%)$ & $311(28 \%)$ & $1,083(30 \%)$ \\
\hline Body mass index $>25$ & $1,453(59 \%)$ & $639(58 \%)$ & $2,092(59 \%)$ \\
\hline Chronic kidney disease & $120(4.9 \%)$ & $46(4.2 \%)$ & $166(4.7 \%)$ \\
\hline Diabetes & $281(11 \%)$ & $153(14 \%)$ & $434(12 \%)$ \\
\hline Down syndrome & $1(<0.1 \%)$ & $2(0.2 \%)$ & $3(0.1 \%)$ \\
\hline Current or former smoker & $359(15 \%)$ & $178(16 \%)$ & $537(15 \%)$ \\
\hline Current or history of substance abuse & $26(1.1 \%)$ & $9(0.8 \%)$ & $35(1.0 \%)$ \\
\hline Immunosuppressive disease or treatment ${ }^{\mathrm{b}}$ & $383(16 \%)$ & $169(15 \%)$ & $552(16 \%)$ \\
\hline Sickle cell disease & $4(0.2 \%)$ & $0(0 \%)$ & $4(0.1 \%)$ \\
\hline Cardiovascular disease & $378(15 \%)$ & $181(16 \%)$ & $559(16 \%)$ \\
\hline Hypertension & $732(30 \%)$ & $341(31 \%)$ & $1,073(30 \%)$ \\
\hline Respiratory condition & $536(22 \%)$ & $243(22 \%)$ & 779 (22\%) \\
\hline Age $12-17$ years with qualifying criterion & $26(1.1 \%)$ & $6(0.5 \%)$ & $32(0.9 \%)$ \\
\hline
\end{tabular}

${ }^{\text {a }}$ Race was reported by the patients

bImmunosuppressive disease or treatment was defined as a history of HIV, cancer, transplant (solid organ, stem cell, bone marrow), chemotherapy treatment, lupus, rheumatoid arthritis, or liver disease

Abbreviations: SD: standard deviation; EUA: emergency use authorization 
medRxiv preprint doi: https://doi.org/10.1101/2021.12.23.21268244; this version posted December 27, 2021. The copyright holder for this preprint (which was not certified by peer review) is the author/funder, who has granted medRxiv a license to display the preprint in perpetuity. All rights reserved. No reuse allowed without permission.

mAb effectiveness in Delta

Table 3. Primary Outcomes from comparative effectiveness trial

\begin{tabular}{|c|c|c|}
\hline & $\begin{array}{c}\text { Casirivimab } \\
+ \text { Imdevimab }\end{array}$ & Sotrovimab \\
\hline No. & 2,454 & 1,104 \\
\hline \multicolumn{3}{|l|}{ Primary Outcome } \\
\hline Hospital-free days, median (IQR) & $28(28-28)$ & $28(28-28)$ \\
\hline Patients with 28 hospital-free days, $\mathrm{n}(\%)$ & $2,163(88.1 \%)$ & $964(87.3 \%)$ \\
\hline \multicolumn{3}{|l|}{ Subcomponents of hospital-free days } \\
\hline Deaths, n (\%) & $12(0.5 \%)$ & $7(0.6 \%)$ \\
\hline Hospital length of stay among hospitalized patients, median days (IQR) & $4(2-8)$ & $4(2-8)$ \\
\hline Hospitalized, $n(\%)$ & $291(11.9 \%)$ & $140(12.7 \%)$ \\
\hline After mAb infusion in emergency department & 262 of $1,399(18.7 \%)$ & 113 of $648(17.4 \%)$ \\
\hline After mAb infusion in infusion center & 29 of $1,055(2.7 \%)$ & 27 of $456(5.9 \%)$ \\
\hline \multicolumn{3}{|l|}{ Primary Analysis } \\
\hline \multicolumn{3}{|l|}{ Adjusted odds ratio } \\
\hline Mean (SD) & $0.89(0.11)$ & 1 [Reference] \\
\hline Median (95\% credible interval) & $0.88(0.70-1.11)$ & 1 [Reference] \\
\hline Probability of inferiority to casirivimab + imdevimab & & $86 \%$ \\
\hline Probability of inferiority to sotrovimab & $14 \%$ & \\
\hline \multicolumn{3}{|l|}{ Probability of equivalence within an odds ratio bound of, \% } \\
\hline 0.25 & \multicolumn{2}{|c|}{$79 \%$} \\
\hline 0.20 & \multicolumn{2}{|c|}{$67 \%$} \\
\hline 0.15 & \multicolumn{2}{|c|}{$53 \%$} \\
\hline 0.10 & \multicolumn{2}{|c|}{$36 \%$} \\
\hline 0.05 & \multicolumn{2}{|c|}{$19 \%$} \\
\hline
\end{tabular}

Abbreviations: IQR: interquartile range; mAb: monoclonal antibodies; SD: standard deviation 
medRxiv preprint doi: https://doi.org/10.1101/2021.12.23.21268244; this version posted December 27, 2021. The copyright holder for this preprint (which was not certified by peer review) is the author/funder, who has granted medRxiv a license to display the preprint in perpetuity.

mAb effectiveness in Delta

\section{Supplementary Materials}

Huang DT, McCreary EK, Bariola JR, et al. Effectiveness of casirivimab and imdevimab, and sotrovimab during the Delta variant surge: a prospective cohort study and comparative effectiveness randomized trial

\section{Supplement 1 - Online Supplemental Materials}

eFigure 1. SARS-CoV-2 Variants of Concern Proportion in Pennsylvania During the Study

eFigure 2. Propensity Scores for Unmatched and Matched Patients

eTable 1. Comparison of Characteristics of Unmatched and Propensity Matched Patients

eTable 2. Primary and Secondary Outcomes in an Unmatched Cohort of Patients Receiving Monoclonal

Antibody Treatment and an At-Risk Population of Patients Not Receiving Monoclonal Antibody

Treatment

Supplement 2 - CONSORT Pragmatic Trials Checklist 
medRxiv preprint doi: https://doi.org/10.1101/2021.12.23.21268244; this version posted December 27, 2021. The copyright holder for this preprint (which was not certified by peer review) is the author/funder, who has granted medRxiv a license to display the preprint in perpetuity. All rights reserved. No reuse allowed without permission.

mAb effectiveness in Delta

\section{Supplement 1 - Online Supplemental Materials}

eFigure 1. SARS-CoV-2 Variants of Concern Proportion in Pennsylvania During the Study (July 14 September 22, 2021).

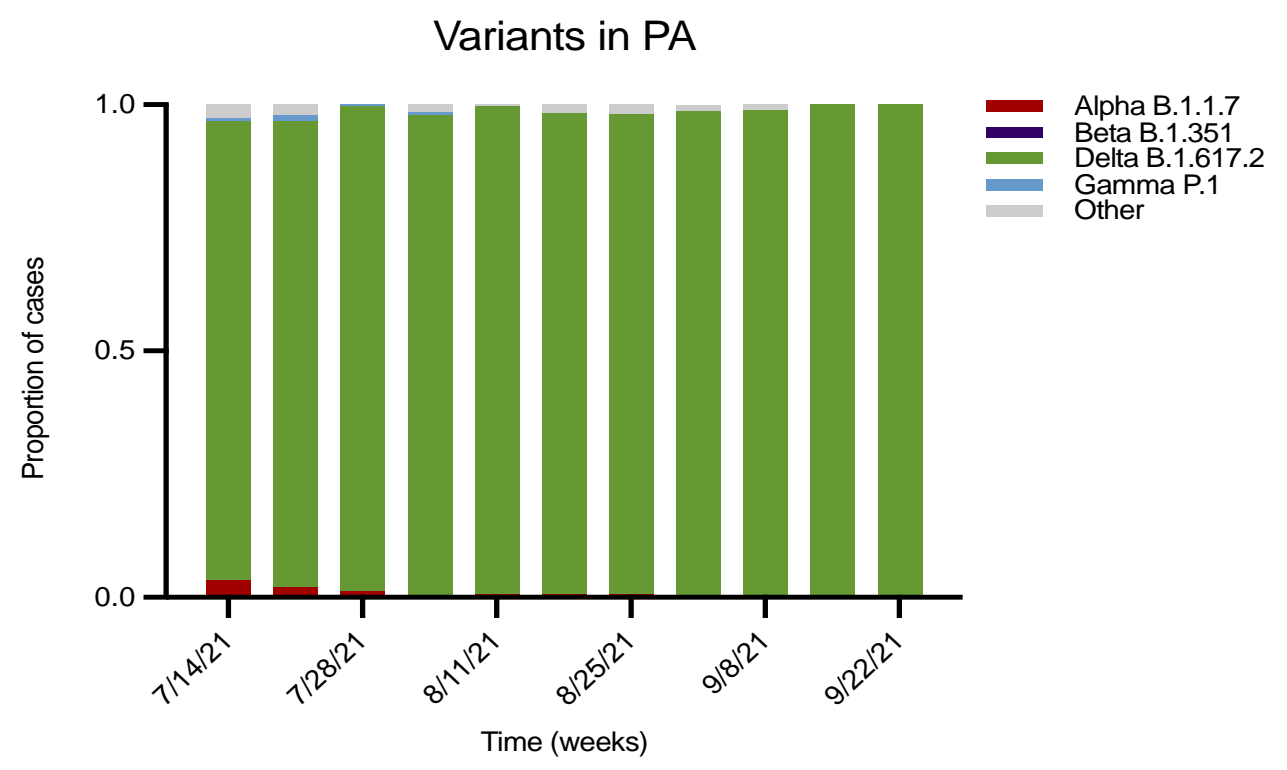

Red represents Alpha B.1.1.7, purple is Beta B.1.351, green is Delta B.1.617.2, and blue is Gamma P.1. 
medRxiv preprint doi: https://doi.org/10.1101/2021.12.23.21268244; this version posted December 27, 2021. The copyright holder for this preprint (which was not certified by peer review) is the author/funder, who has granted medRxiv a license to display the preprint in perpetuity.

All rights reserved. No reuse allowed without permission.

mAb effectiveness in Delta

eFigure 2. Propensity Scores for Unmatched and Matched Patients

\section{Propensity}

Score (x 100)

35

30

25

20

15

10

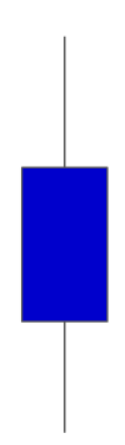

Unmatched

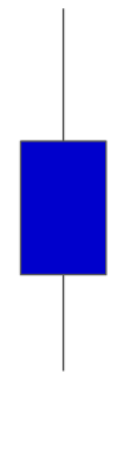

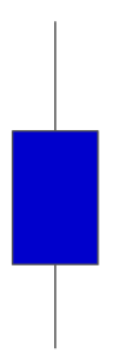
$(\mathrm{n}=\mathbf{5 1 7 1})$
$C+I(n=717) \quad S(n=311)$

\section{Matched}
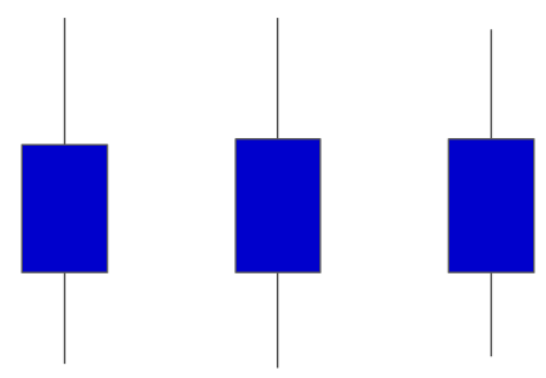

Not Treated
$(\mathbf{n}=\mathbf{2 0 4 6})$

After propensity score matching, treated and non-mAb treated patients were similar on the distribution of propensity scores. 
medRxiv preprint doi: https://doi.org/10.1101/2021.12.23.21268244; this version posted December 27, 2021. The copyright holder for this preprint (which was not certified by peer review) is the author/funder, who has granted medRxiv a license to display the preprint in perpetuity. All rights reserved. No reuse allowed without permission.

mAb effectiveness in Delta

eTable 1. Comparison of Characteristics of Unmatched and Propensity Matched Patients

\begin{tabular}{|c|c|c|c|c|c|c|}
\hline & \multicolumn{3}{|c|}{ Unmatched } & \multicolumn{3}{|c|}{ Propensity Matched } \\
\hline & Treated & Not Treated & p-value & Treated & Not Treated & p-value \\
\hline No. & 1,028 & 5,171 & & 1,023 & 2,046 & \\
\hline \multicolumn{7}{|l|}{ Patient Characteristics } \\
\hline Age, mean (SD) & $53.2(16.4)$ & $49.6(21.4)$ & $<.001$ & $53.2(16.4)$ & $52.8(19.5)$ & .50 \\
\hline Female gender, (No.), \% & (572) $55.6 \%$ & (3013) 58.3\% & .12 & (569) $55.6 \%$ & (1157) 56.6\% & .62 \\
\hline Black race, (No.), \% & (61) $5.9 \%$ & (590) $11.4 \%$ & $<.001$ & (61) $6.0 \%$ & (112) $5.5 \%$ & .58 \\
\hline Body mass index, mean (SD) & $32.5(7.4)$ & $31.8(7.5)$ & .008 & $32.5(7.4)$ & $32.6(7.8)$ & .60 \\
\hline \multicolumn{7}{|l|}{ Medical History } \\
\hline History of cancer, (No.), \% & (46) $4.5 \%$ & (597) $11.6 \%$ & $<.001$ & (42) $4.1 \%$ & (105) $5.1 \%$ & .21 \\
\hline History of congestive heart failure, (No.), \% & (47) $4.6 \%$ & (399) $7.7 \%$ & $<.001$ & (46) $4.5 \%$ & (93) $4.6 \%$ & .95 \\
\hline History of obstructive sleep apnea, (No.), \% & (198) $19.3 \%$ & (743) $14.4 \%$ & $<.001$ & (195) $19.1 \%$ & (338) $16.5 \%$ & .08 \\
\hline Charlson Comorbidity Index Score, mean (SD) & $0.7(0.9)$ & $0.9(1.2)$ & $<.001$ & $0.7(0.9)$ & $0.7(0.9)$ & .57 \\
\hline History of rheumatoid arthritis, (No.), \% & (38) $3.7 \%$ & (104) $2.0 \%$ & .001 & (34) $3.3 \%$ & (61) $3.0 \%$ & .61 \\
\hline History of atrial fibrillation, (No.), \% & (46) $4.5 \%$ & (307) 5.9\% & .06 & (46) $4.5 \%$ & (90) $4.4 \%$ & .90 \\
\hline History of valvular heart disease, (No.), \% & (73) $7.1 \%$ & (287) $5.6 \%$ & .05 & (72) $7.0 \%$ & (138) 6.7\% & .76 \\
\hline History of viral hepatitis, (No.), \% & (7) $0.7 \%$ & (79) $1.5 \%$ & .03 & (7) $0.7 \%$ & (16) $0.8 \%$ & .77 \\
\hline Antidepressants, (No.), \% & (335) $32.6 \%$ & (1497) $29.0 \%$ & .02 & (330) $32.3 \%$ & (674) $32.9 \%$ & .70 \\
\hline History of asthma, (No.), \% & (312) 30.4\% & (1851) $35.8 \%$ & $<.001$ & (311) $30.4 \%$ & (593) $29.0 \%$ & .42 \\
\hline History of stroke, (No.), \% & (45) $4.4 \%$ & (305) 5.9\% & .05 & (45) $4.4 \%$ & (91) $4.5 \%$ & .95 \\
\hline History of allergic rhinitis, (No.), \% & (146) $14.2 \%$ & (658) $12.7 \%$ & .20 & (145) $14.2 \%$ & (268) $13.1 \%$ & .41 \\
\hline Alpha blockers, (No.), \% & (11) $1.1 \%$ & (78) $1.5 \%$ & .28 & (11) $1.1 \%$ & (20) $1.0 \%$ & .80 \\
\hline \multicolumn{7}{|l|}{ Variables Not Included in Propensity Model } \\
\hline ACE Inhibitors, (No.), \% & (144) $14.0 \%$ & (759) $14.7 \%$ & .58 & (144) $14.1 \%$ & (303) $14.8 \%$ & .59 \\
\hline Angiotensin II receptor blocker, (No.), \% & (104) $10.1 \%$ & (450) $8.7 \%$ & .15 & (102) $10.0 \%$ & (195) 9.5\% & .70 \\
\hline Beta blockers, (No.), \% & (215) $20.9 \%$ & (1114) $21.5 \%$ & .65 & (212) $20.7 \%$ & (462) $22.6 \%$ & .24 \\
\hline History of coronary artery disease, (No.), \% & (104) $10.1 \%$ & (542) $10.5 \%$ & .73 & (103) $10.1 \%$ & (188) $9.2 \%$ & .43 \\
\hline History of chronic kidney disease, (No.), \% & (53) $5.2 \%$ & (336) 6.5\% & .11 & (53) $5.2 \%$ & (117) 5.7\% & .54 \\
\hline History of COPD, (No.), \% & (148) $14.4 \%$ & (831) $16.1 \%$ & .18 & (146) $14.3 \%$ & (272) $13.3 \%$ & .46 \\
\hline Corticosteroids, (No.), \% & (348) $33.9 \%$ & (1639) $31.7 \%$ & .18 & (345) $33.7 \%$ & (653) 31.9\% & .31 \\
\hline History of diabetes, (No.), \% & (167) $16.3 \%$ & (883) $17.1 \%$ & .52 & (166) $16.2 \%$ & (331) $16.2 \%$ & .97 \\
\hline History of dyspnea, (No.), \% & (51) $5.0 \%$ & (295) $5.7 \%$ & .34 & (51) $5.0 \%$ & (104) 5.1\% & .91 \\
\hline History of fatty liver disease, (No.), \% & (34) $3.3 \%$ & (143) $2.8 \%$ & .34 & (34) $3.3 \%$ & (59) $2.9 \%$ & .50 \\
\hline History of hypertension, (No.), \% & (426) $41.4 \%$ & (2070) 40.0\% & .40 & (423) $41.4 \%$ & (861) $42.1 \%$ & .70 \\
\hline History of pulmonary hypertension, (No.), \% & (8) $0.8 \%$ & (102) $2.0 \%$ & .008 & (8) $0.8 \%$ & (30) $1.5 \%$ & .11 \\
\hline Statins, (No.), \% & (320) $31.1 \%$ & (1485) $28.7 \%$ & .12 & (318) $31.1 \%$ & (630) $30.8 \%$ & .87 \\
\hline
\end{tabular}


medRxiv preprint doi: https://doi.org/10.1101/2021.12.23.21268244; this version posted December 27, 2021. The copyright holder for this preprint (which was not certified by peer review) is the author/funder, who has granted medRxiv a license to display the preprint in perpetuity.

All rights reserved. No reuse allowed without permission.

mAb effectiveness in Delta

eTable 2. Primary and secondary outcomes in an unmatched cohort of patients receiving monoclonal antibody treatment and an at-risk population of patients not receiving treatment

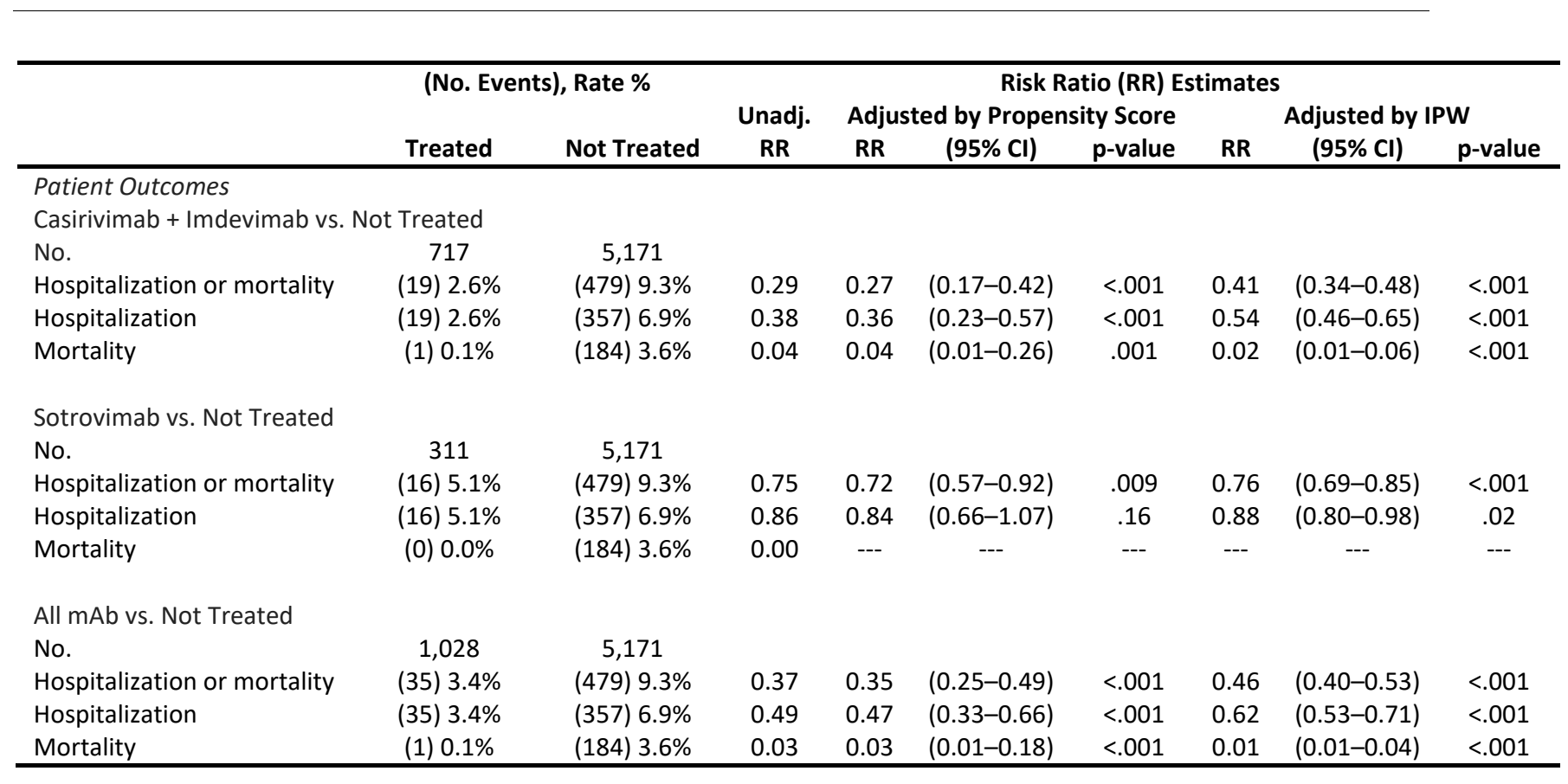


medRxiv preprint doi: https://doi.org/10.1101/2021.12.23.21268244; this version posted December 27, 2021. The copyright holder for this preprint (which was not certified by peer review) is the author/funder, who has granted medRxiv a license to display the preprint in perpetuity.

All rights reserved. No reuse allowed without permission.

mAb effectiveness in Delta

\section{Supplement 2 - CONSORT Pragmatic Trials Checklist}

\begin{tabular}{|c|c|c|c|c|}
\hline Section & Item & Standard CONSORT Description & Pragmatic Trials Extension & Page \\
\hline Title and abstract & 1 & $\begin{array}{l}\text { How participants were allocated to } \\
\text { interventions (e.g., "random allocation," } \\
\text { "randomized," or "randomly assigned") }\end{array}$ & & $\begin{array}{l}\text { Title } \\
\text { page } 1 \\
\& \\
\text { Abstract } \\
\text { pages } 4- \\
5\end{array}$ \\
\hline \multicolumn{5}{|l|}{ Introduction } \\
\hline Background & 2 & $\begin{array}{l}\text { Scientific background and explanation of } \\
\text { rationale }\end{array}$ & $\begin{array}{l}\text { Describe the health or health } \\
\text { service problem that the } \\
\text { intervention is intended to } \\
\text { address and other interventions } \\
\text { that may commonly be aimed at } \\
\text { this problem }\end{array}$ & 6 \\
\hline \multicolumn{5}{|l|}{ Methods } \\
\hline Participants & 3 & $\begin{array}{l}\text { Eligibility criteria for participants; settings } \\
\text { and locations where the data were } \\
\text { collected }\end{array}$ & $\begin{array}{l}\text { Eligibility criteria should be } \\
\text { explicitly framed to show the } \\
\text { degree to which they include } \\
\text { typical participants and/or, } \\
\text { where applicable, typical } \\
\text { providers (e.g., nurses), } \\
\text { institutions (e.g., hospitals), } \\
\text { communities (or localities e.g., } \\
\text { towns) and settings of care (e.g., } \\
\text { different healthcare financing } \\
\text { systems) }\end{array}$ & $8-9$ \\
\hline \multirow[t]{2}{*}{ Interventions } & 4 & $\begin{array}{l}\text { Precise details of the interventions } \\
\text { intended for each group and how and } \\
\text { when they were actually administered }\end{array}$ & $\begin{array}{l}\text { Describe extra resources added } \\
\text { to (or resources removed from) } \\
\text { usual settings in order to } \\
\text { implement intervention. } \\
\text { Indicate if efforts were made to } \\
\text { standardize the intervention or } \\
\text { if the intervention and its } \\
\text { delivery were allowed to vary } \\
\text { between participants, } \\
\text { practitioners, or study sites }\end{array}$ & - \\
\hline & & & $\begin{array}{l}\text { Describe the comparator in } \\
\text { similar detail to the intervention }\end{array}$ & - \\
\hline Objectives & 5 & Specific objectives and hypotheses & & 6 \\
\hline Outcomes & 6 & $\begin{array}{l}\text { Clearly defined primary and secondary } \\
\text { outcome measures and, when applicable, } \\
\text { any methods used to enhance the quality } \\
\text { of measurements (e.g., multiple } \\
\text { observations, training of assessors) }\end{array}$ & $\begin{array}{l}\text { Explain why the chosen } \\
\text { outcomes and, when relevant, } \\
\text { the length of follow-up is } \\
\text { considered important to those } \\
\text { who will use the results of the } \\
\text { trial }\end{array}$ & $7-8$ \\
\hline Sample size & 7 & $\begin{array}{l}\text { How sample size was determined; } \\
\text { explanation of any interim analyses and } \\
\text { stopping rules when applicable }\end{array}$ & $\begin{array}{l}\text { If calculated using the smallest } \\
\text { difference considered important } \\
\text { by the target decision maker } \\
\text { audience (the minimally } \\
\text { important difference) then }\end{array}$ & - \\
\hline
\end{tabular}


medRxiv preprint doi: https://doi.org/10.1101/2021.12.23.21268244; this version posted December 27, 2021. The copyright holder for this preprint (which was not certified by peer review) is the author/funder, who has granted medRxiv a license to display the preprint in perpetuity.

All rights reserved. No reuse allowed without permission.

\section{mAb effectiveness in Delta}

\begin{tabular}{|c|c|c|c|c|}
\hline Section & Item & Standard CONSORT Description & Pragmatic Trials Extension & Page \\
\hline & & & $\begin{array}{l}\text { report where this difference was } \\
\text { obtained }\end{array}$ & \\
\hline $\begin{array}{l}\text { Randomization- } \\
\text { sequence generation }\end{array}$ & 8 & $\begin{array}{l}\text { Method used to generate the random } \\
\text { allocation sequence, including details of } \\
\text { any restriction (e.g., blocking, stratification) }\end{array}$ & & - \\
\hline $\begin{array}{l}\text { Randomization- } \\
\text { allocation } \\
\text { concealment }\end{array}$ & 9 & $\begin{array}{l}\text { Method used to implement the random } \\
\text { allocation sequence (e.g., numbered } \\
\text { containers or central telephone), clarifying } \\
\text { whether the sequence was concealed until } \\
\text { interventions were assigned }\end{array}$ & & $11-12$ \\
\hline $\begin{array}{l}\text { Randomization- } \\
\text { implementation }\end{array}$ & 10 & $\begin{array}{l}\text { Who generated the allocation sequence, } \\
\text { who enrolled participants, and who } \\
\text { assigned participants to their groups }\end{array}$ & & - \\
\hline Blinding (masking) & 11 & $\begin{array}{l}\text { Whether participants, those administering } \\
\text { the interventions, and those assessing the } \\
\text { outcomes were blinded to group } \\
\text { assignment }\end{array}$ & $\begin{array}{l}\text { If blinding was not done, or was } \\
\text { not possible, explain why }\end{array}$ & 11 \\
\hline Statistical methods & 12 & $\begin{array}{l}\text { Statistical methods used to compare } \\
\text { groups for primary outcomes; methods for } \\
\text { additional analyses, such as subgroup } \\
\text { analyses and adjusted analyses }\end{array}$ & & $11-12$ \\
\hline \multicolumn{5}{|l|}{ Results } \\
\hline Participant flow & 13 & $\begin{array}{l}\text { Flow of participants through each stage (a } \\
\text { diagram is strongly recommended)- } \\
\text { specifically, for each group, report the } \\
\text { numbers of participants randomly } \\
\text { assigned, receiving intended treatment, } \\
\text { completing the study protocol, and } \\
\text { analyzed for the primary outcome; } \\
\text { describe deviations from planned study } \\
\text { protocol, together with reasons }\end{array}$ & $\begin{array}{l}\text { The number of participants or } \\
\text { units approached to take part in } \\
\text { the trial, the number which } \\
\text { were eligible, and reasons for } \\
\text { non-participation should be } \\
\text { reported }\end{array}$ & 11 \\
\hline Recruitment & 14 & $\begin{array}{l}\text { Dates defining the periods of recruitment } \\
\text { and follow-up }\end{array}$ & & - \\
\hline Baseline data & 15 & $\begin{array}{l}\text { Baseline demographic and clinical } \\
\text { characteristics of each group }\end{array}$ & & 13 \\
\hline Numbers analyzed & 16 & $\begin{array}{l}\text { Number of participants (denominator) in } \\
\text { each group included in each analysis and } \\
\text { whether analysis was by "intention-to- } \\
\text { treat;" state the results in absolute } \\
\text { numbers when feasible (e.g., } 10 / 20 \text {, not } \\
50 \% \text { ) }\end{array}$ & & 13 \\
\hline $\begin{array}{l}\text { Outcomes and } \\
\text { estimation }\end{array}$ & 17 & $\begin{array}{l}\text { For each primary and secondary outcome, } \\
\text { a summary of results for each group and } \\
\text { the estimated effect size and its precision } \\
\text { (e.g., } 95 \% \mathrm{Cl} \text { ) }\end{array}$ & & $14-15$ \\
\hline Ancillary analyses & 18 & $\begin{array}{l}\text { Address multiplicity by reporting any other } \\
\text { analyses performed, including subgroup } \\
\text { analyses and adjusted analyses, indicating } \\
\text { which are prespecified and which are } \\
\text { exploratory }\end{array}$ & & 15 \\
\hline
\end{tabular}


medRxiv preprint doi: https://doi.org/10.1101/2021.12.23.21268244; this version posted December 27, 2021. The copyright holder for this preprint (which was not certified by peer review) is the author/funder, who has granted medRxiv a license to display the preprint in perpetuity. All rights reserved. No reuse allowed without permission.

\section{mAb effectiveness in Delta}

\begin{tabular}{|c|c|c|c|c|}
\hline Section & Item & Standard CONSORT Description & Pragmatic Trials Extension & Page \\
\hline Adverse events & 19 & $\begin{array}{l}\text { All-important adverse events or side effects } \\
\text { in each intervention group }\end{array}$ & & 15 \\
\hline \multicolumn{5}{|l|}{ Discussion } \\
\hline Interpretation & 20 & $\begin{array}{l}\text { Interpretation of the results, considering } \\
\text { study hypotheses, sources of potential bias } \\
\text { or imprecision, and the dangers associated } \\
\text { with multiplicity of analyses and outcomes }\end{array}$ & & $16-17$ \\
\hline Generalizability & 21 & $\begin{array}{l}\text { Generalizability (external validity) of the } \\
\text { trial findings }\end{array}$ & $\begin{array}{l}\text { Describe key aspects of the } \\
\text { setting which determined the } \\
\text { trial results. Discuss possible } \\
\text { differences in other settings } \\
\text { where clinical traditions, health } \\
\text { service organization, staffing, or } \\
\text { resources may vary from those } \\
\text { of the trial }\end{array}$ & $16-18$ \\
\hline Overall evidence & 22 & $\begin{array}{l}\text { General interpretation of the results in the } \\
\text { context of current evidence }\end{array}$ & & 18 \\
\hline
\end{tabular}

